\title{
Spatial and temporal variation of Peridinium umbonatum F. Stein, 1883 (Dinophyceae) and its relationship with total phytoplankton of a shallow, oligotrophic lake in central Brazil (Lagoon Bonita, Distrito Federal)
}

\author{
Variação especial e temporal de Peridinium umbonatum F. Stein, 1883 \\ (Dinophyceae) e sua relaçáo com o fitoplâncton total de uma lagoa rasa \\ e oligotrófica no Brasil Central (Lagoa Bonita, Distrito Federal)
}

Patrícia Pereira Gomes, Maria do Socorro Rodrigues Ibañez and June Springer de Freitas

Departamento de Ecologia, Universidade de Brasília - UnB, Campus Darcy Ribeiro, Asa Norte, CEP 70910-900, Brasília, DF, Brazil e-mail: patriciapgl@gmail.com, marias@unb.br, june@unb.br

\begin{abstract}
Aim: The main goal of this study was to investigate the temporal and spatial distribution of Peridinium umbonatum and its relationship with the physical and chemical water variables of the pelagic and littoral zones of Lagoon Bonita, located in Brasília, Distrito Federal; Methods: Samples were collected at three stations: two in the littoral zone and one in the pelagic zone, every 15 days from April 2005 through March 2006; Results: P. umbonatum was the only member of class Dinophyceae recorded during the entire seasonal cycle, with few exceptions, in both the littoral and pelagic zones of Lagoon Bonita. The highest biovolume $\left(7.5 \mathrm{~mm}^{3} \cdot \mathrm{L}^{-1}\right)$ of this alga occurred near shore at the beginning of the rainy season, in November 2005. Smaller values of $P$. umbonatum biovolume were recorded in May and June 2005, typical dry months; Conclusions: $P$. umbonatum and the phytoplankton community as a whole had higher biovolumes in the two littoral zone sites, at the end of the dry season and the beginning of the rains. Both, the temporal and spatial scales were relevant in the presence of $P$. umbonatum, and the spatial heterogeneity was the dominant factor along the study period. The plant community structure, mainly submersed macrophytes, has affected the $P$. umbonatum population dynamics that took place at shallow, nutrientpoor conditions, small-size lake, which matches with habitat template described to Lo functional classification established by Reynolds et al. (2002).
\end{abstract}

Keywords: Peridinium umbonatum, tropical lake, Cerrado, Central Brazil.

Resumo: Objetivos: O principal objetivo deste estudo foi investigar a distribuição temporal e espacial de Peridinium umbonatum e sua relaçấo com as variáveis físicas e químicas da água das zonas pelágica e litorânea da Lagoa Bonita, localizada em Brasília, Distrito Federal; Métodos: As amostras foram coletadas em três estaçóes: duas na zona litorânea e uma na zona pelágica, a cada 15 dias, de abril de 2005 a março de 2006; Resultados: P. umbonatum foi o único membro da classe Dinophyceae registrado durante todo o ciclo sazonal, com poucas exceçóes, tanto nas zonas litorâneas quanto na zona pelágica da Lagoa Bonita. O maior biovolume dessa alga $\left(7,5 \mathrm{~mm}^{3} . \mathrm{L}^{-1}\right)$ ocorreu perto da costa, no início da estação chuvosa, em novembro de 2005. Os menores valores de biovolume $P$. umbonatum foram registrados em maio e junho de 2005, meses tipicamente secos; Conclusóes: $P$. umbonatum e a comunidade fitoplanctônica como um todo tiveram os maiores biovolumes nos dois pontos da zona litorânea, no final da estação seca e início das chuvas. Tanto a escala temporal quanto a espacial foram relevantes na ocorrência de P. umbonatum, sendo que a heterogeneidade espacial foi o fator preponderante durante o período de estudo. A estrutura das comunidades de plantas, sobretudo macrófitas submersas, influenciaram na dinâmica populacional de $P$. umbanatum que ocorreu em um lago raso, pobre em nutrientes e de tamanho pequeno, cujas características coincidem com as características de habitat descritas para o grupo funcional Lo estabelecido por Reynolds et al. (2002).

Palavras-chave: Peridinium umbonatum, lago tropical, Cerrado, Brasil Central. 


\section{Introduction}

Freshwater dinoflagellates are unicellular organisms that inhabit, alternately, the plankton as mobile vegetative cells and the benthos as cysts. The group includes 2000 species in approximately 130 genera (Taylor, 1987). Little is known about the factors that influence their occurrence (Grigorszky et al., 2003).

These phytoplankton organisms, because of their mobility, are better adapted to exploit heterogeneous environments, with nutrients furnished by the presence of macrophytes (Sommer, 1988; Søndegaard and Moss, 1998).

According to Pollingher (1988), dinoflagellates need turbulence during the period of resuspension of their cysts, which are the inocula for new populations. Nevertheless, because of their motility they do not need turbulence to remain in the upper layers of the water column. This ability facilitates their search for nutrients in the water column, and simultaneously reduces nutrient loss by sedimentation. Other features such as low $\mathrm{P}$ consumption, vertical migration capability, and relatively long life span confer on dinoflagellates a great competitive advantage over other algae under extreme conditions of nutrient depletion. Also, because of their relatively large size, dinoflagellates are less susceptible to zooplankton grazing, minimizing their losses (Pollingher, 1988). Freshwater dinoflagellates typically store phosphorus for several generations in environments that are deficient in this nutrient, as reported by Serruya and Bermann (1975) in a study in Kinneret Lake on the relationship between nutrients and algal growth.

Little is known about the diversity of dinoflagellates in Brazilian continental waters. A pioneer study in a shallow oligotrophic tropical ecosystem concerning temporal and spatial variation of Peridinium was performed by Oda and Bicudo (2006), at the Biological Reservoir of the Ipiranga Springs State Park, São Paulo.

Cardoso and Torgan (2007), working with dinoflagellates in different habitats on the Brazilian southern coast, found that two species of Peridinium were good habitat indicators: $P$. umbonatum Stein, 1883 in shallow closed lagoons, and P. gatunense Nygaard, 1925 during the period of high water. These authors suggested that these two species could be used in future monitoring of habitat conservation and local climate changes. In studies on phytoplankton functional groups in a shallow oligotrophic lake of the Vale Bloqueado in central
Brazil, Nabout and Nogueira (2007) found spatial differences in the phytoplankton biovolume of lotic and lentic environments, confirming the dominance of dinoflagellates in the lentic stations, with the occurrence of $P$. umbonatum and $P$. corillionii.

Fonseca and Bicudo (2010) studied phytoplankton taxonomic classes and morphofunctional attributes in two shallow tropical reservoirs in the state of Sáo Paulo, with different nutrient levels, and in the oligomesotrophic environment of Ninféias Lake, found P. umbonatum and $P$. gatunense. The presence of macrophytes in this lake also seemed to qualitatively influence its phytoplankton community, favoring flagellated species.

Taxonomic studies conducted in different Brazilian ecosystems have recorded species of Peridinium. Rosa et al. (1987), in the southern region, mentioned the occurrence of $P$. gatunense in small reservoirs along the lower Jacui River. Franceschini (1992) recorded P. volzii Lemmermann and Peridiniopsis oculatum (Stein) Bourrelly in Guaíba Lake and some artificial lakes of Porto Alegre; Garcia and Vélez (1995) listed P. umbonatum as occurring in the Emboaba coastal lagoon. In the southeast, Silva (1999) reported P. umbonatum, P. volzii, and two other unidentified species of Peridinium in a eutrophic lake in Monte Alegre. In São Paulo state, Delazari-Barroso et al. (2007) recorded Peridinium africanum, P. gutwinskii and P. umbonatum in Duas Bocas Reservoir in the state of Espírito Santo.

In the Northeastern region, Peridinium species were recorded in pristine dune lagoons in the Lençóis Maranhenses National Park (Moschini-Carlos et al., 2008) and in the natural lagoon of Extremos, Natal, Rio Grande do Norte (Araújo et al., 2000).

Dinoflagellates are usually found in welloxygenated waters and are adapted to a wide range of $\mathrm{pH}$ and light conditions, for which reason they are considered indicators of oligotrophic environments, as is the case for Lagoon Bonita (Fonseca, 2005).

This lake is part of the Águas Emendadas Conservation Unit, where in recent years urban and agricultural development has increased within its boundaries, especially corn and soybean crops and cattle ranching. According to Aquino-Leite (1990), in 1989 Lagoon Bonita was oligotrophic, with acid $\mathrm{pH}$ and an abundant desmid flora. However, no investigators have examined the lagoon's physical and chemical characteristics and possible changes in the plankton until the present study. 
Therefore, we investigated the spatial and temporal distribution of Peridinium umbonatum, described by Popovský and Pfiester (1990) and its relationship with physical and chemical variables in the pelagic and littoral zones of the lake.

\section{Material and Methods}

\subsection{Study area}

Lagoon Bonita is a shallow tropical lake (maximum depth $3.5 \mathrm{~m}$, mean depth $1.8 \mathrm{~m}$ ) with a surface area of 120 ha, located within a conservation area in Central Brazil (Figure 1). It is situated in the northeast part of the Federal District $\left(15^{\circ} 32^{\prime}\right.$ to $15^{\circ} 38^{\prime} \mathrm{S}$ and $47^{\circ} 33^{\prime}$ to $\left.47^{\circ} 37^{\prime} \mathrm{W}\right)$. The water is transparent, with the bottom covered by macrophytes (families Lentibulariaceae and Mayacacea). Its oligotrophic characteristics make it a reference system in the central Brazil region, appropriate for ecological studies of well-preserved aquatic environments (Gomes, 2007).

\subsection{Sampling techniques}

Two of the three sampling sites were located in the littoral zone, and the remaining one in the pelagic zone (Figure 1). Station 1 (littoral) was situated in a shallow area near shore $(0.79 \pm$ $0.13 \mathrm{~m}$ ), close to the agricultural areas, with floating and submersed macrophytes. Station 2 (pelagic) was situated in the center of the lagoon (limnetic zone, $2.14 \pm 0.15 \mathrm{~m}$ ), where the macrophytes form a deep carpet that remains submersed. Station 3 (littoral), also located near the shore $(1.09 \pm 0.15 \mathrm{~m})$ has both submersed and floating macrophytes.

Subsurface water samples were collected for physical, chemical and biological analysis. Samplings were always performed in the morning at intervals of 2 weeks. Samples for analysis of phytoplankton (density and biovolume), water temperature, $\mathrm{pH}$, electrical conductivity, and dissolved oxygen were collected from April 2005 to March 2006. Starting from September 2005 until the end of the sampling period, samples for nutrient determination (Nitrogen and total Phosphorus) were also collected. Rainfall data were supplied by Embrapa's CPAC Meteorological Station in the northeast part of the Federal District (15 35' 30"S and $47^{\circ} 42^{\prime} 30^{\prime \prime} \mathrm{W}$ ).

Water temperature was taken in loco with a mercury thermometer $\left(0.1{ }^{\circ} \mathrm{C}\right)$. Electrical conductivity and $\mathrm{pH}$ were measured with an OAKTON meter. Dissolved oxygen concentration (DO) was determined according to the Winkler titration method described in Wetzel and Likens (2001). Total nitrogen and phosphorus concentrations were analyzed soon after collection at the CAESB Water Sanitation and Treatment Laboratory of the city of Brasília, according to APHA (1995).

Samples for quantitative and qualitative analyses were fixed in loco, with Transeau solution and 1\% acetic Lugol, respectively (Bicudo and Menezes, 2005). For qualitative analysis, a Carl Zeiss model HAL 100 optical microscope was used. For taxonomic classification, the system of van den Hoek et al. (1995) was adopted. Phytoplankton quantitative analysis was done according to Utermöhl (1958). Samples were placed in $50 \mathrm{~mL}$ sedimentation chambers as a function of the present organism density; and the individuals were counted with the aid of a Zeiss model Telaval 31 inverted microscope, at 400x. For each sample, 100 fields were counted.

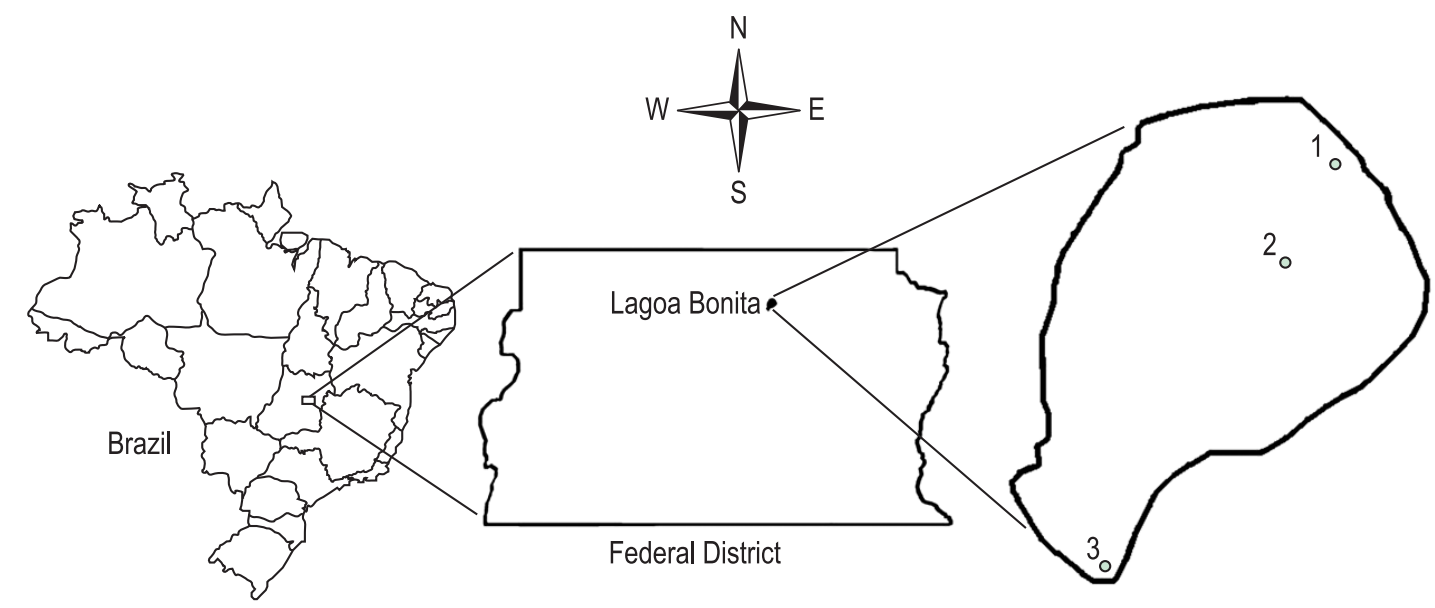

Figure 1. Localization of Lagoon Bonita showing the sampling stations. 
Biomass was calculated by the product between the algae density and their respective cell volumes computed from each individual cell size measurement, based upon geometrical solids that, when isolated or combined, approximate the real cell shape (Hillebrand et al., 1999, Sun and Liu, 2003). Peridinium umbonatum biovolume was estimated by multiplying the density (ind. $\mathrm{mL}^{-1}$ ) times the mean volume of 20 to 30 individuals (Rott, 1981).

The data collected fortnightly for the physical and chemical variables, density and biovolume of $P$. umbonatum and total phytoplankton were compared by an ANOVA test for the three collecting points after log-transformation $(x+1)$ to normalize the data distribution. Whenever at least one of the stations differed from the rest, they were tested in pairs using the Duncan Test. The analyses were conducted using the SPSS 9.0 Statistical Package for Social Science (Nie et al., 1981). Physical and chemical data were compared between the dry and rainy seasons [ANOVA for two paired samples, significance level 0.05, after log-transformation $(\mathrm{x}+1)]$, using the Bioestat 3.0 Statistical package (Ayres et al., 2003).

\section{Results}

Between April and October 2005, the dry months, rainfall ranged from $0 \mathrm{~mm}$ (July/2005) to $57.3 \mathrm{~mm}$ (September/2005). In the rainy season, from November/2005 to March/2006, rainfall ranged from $120.8 \mathrm{~mm}$ (March/2006) to $257.1 \mathrm{~mm}$ (December/2005), except in Jan/2006, when this value was atypical $(53.1 \mathrm{~mm})$ (Figure 2$)$.

Water temperature was $19.0{ }^{\circ} \mathrm{C}$ (June and July/2005, point 1) and $28.0{ }^{\circ} \mathrm{C}$ (April/2005, points 1 and 3), with no significant difference between sampling stations (ANOVA, $\mathrm{F}=0.928$, $\mathrm{p}=0.401)$. Dissolved oxygen $(\mathrm{DO})$ concentration varied from $4.4 \mathrm{mg} . \mathrm{L}^{-1}$ (April/2005) to $9.1 \mathrm{mg} . \mathrm{L}^{-1}$ (May/2005), both at station 2 (Table 1). The $\mathrm{pH}$ was moderately acid in all sampling units, varying from 5.1 (July/2005, station 1) to 6.9 (April/2005, station 3) (Table 1). Electrical conductivity varied from $3.1 \mu S . \mathrm{cm}^{-1}$ (August/2005, station 3) to $12.8 \mu \mathrm{S} . \mathrm{cm}^{-1}$ (October/2005, station 1).

Total Nitrogen (TN) concentration varied from $235 \mu \mathrm{g}$. $\mathrm{L}^{-1}$ (November/2005, station 2) to $757 \mu \mathrm{g} . \mathrm{L}^{-1}$ (February/2006, station 1), with no significant differences among the three sampling stations (ANOVA, $\mathrm{F}=2.863, \mathrm{p}=0.071$ ). Total Phosphorus (TP) concentrations varied between values below the limit of detection (less than $2 \mu \mathrm{g} . \mathrm{L}^{-1}$, pelagic zone) to $66 \mu \mathrm{g} . \mathrm{L}^{-1}$ (littoral zone 1). No significant variation was detected for Total Phosphorus (Table 1) between the littoral and pelagic zones (ANOVA, $\mathrm{F}=1.901, \mathrm{p}=0.165$ ). This variable fluctuated most widely over time, with

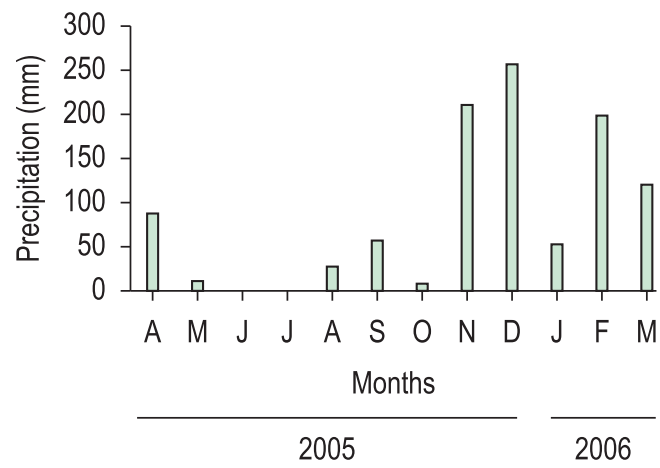

Figure 2. Monthly rainfall data over the study period (EMBRAPA-CPAC).

Table 1. Limnological variable ranges at three sampling points in Lagoon Bonita between April/2005 and March/2006.

\begin{tabular}{|c|c|c|c|}
\hline Variable & Littoral zone (1) & Pelagic zone(2) & Littoral zone (3) \\
\hline Water temperature ${ }^{*}\left({ }^{\circ} \mathrm{C}\right)$ & $\begin{array}{c}19.0-28.0 \\
(23.7 \pm 2.5 ; 10.3 \%)\end{array}$ & $\begin{array}{c}20.0-27.0 \\
(24.0 \pm 2.2 ; 9 \%)\end{array}$ & $\begin{array}{c}21.0-28.0 \\
(24.6 \pm 2.2 ; 9.0 \%)\end{array}$ \\
\hline Dissolved oxygen* $\left(\mathrm{mg.L}^{-1}\right)$ & $\begin{array}{c}4.5-8.9 \\
(6.7 \pm 1.1 ; 16.1 \%)\end{array}$ & $\begin{array}{c}4.4-9.1 \\
(6.9 \pm 1.0 ; 14.5 \%)\end{array}$ & $\begin{array}{c}5.3-8.9 \\
(6.8 \pm 1.0 ; 14.7 \%)\end{array}$ \\
\hline $\mathrm{pH}^{*}$ & $\begin{array}{c}5.3-6.4 \\
(5.9 \pm 0.3 ; 4.8 \%)\end{array}$ & $\begin{array}{c}5.2-6.5 \\
(6.0 \pm 0.3 ; 5.6 \%)\end{array}$ & $\begin{array}{c}5.1-6.9 \\
(5.9 \pm 0.4 ; 6.8 \%)\end{array}$ \\
\hline Electrical conductivity* $\left(\mu \mathrm{S} . \mathrm{cm}^{-1}\right)$ & $\begin{array}{c}3.3-12.8 \\
(5.2 \pm 2.1 ; 39.3 \%)\end{array}$ & $\begin{array}{c}3.2-7.4 \\
(4.5 \pm 1.1 ; 23.9 \%)\end{array}$ & $\begin{array}{c}3.1-7.2 \\
(4.4 \pm 1.0 ; 23.2 \%)\end{array}$ \\
\hline $\operatorname{Depth}^{*}(\mathrm{~m})$ & $\begin{array}{c}0.6-1.1 \\
(0.8 \pm 0.1 ; 12.5 \%)\end{array}$ & $\begin{array}{c}1.8-2.4 \\
(2.1 \pm 0.2 ; 9.5 \%)\end{array}$ & $\begin{array}{c}0.8-1.4 \\
(1.1 \pm 0.1 ; 9.1 \%)\end{array}$ \\
\hline Total Nitrogen ${ }^{\star \star}\left(\mu \mathrm{g} \cdot \mathrm{L}^{-1}\right)$ & $\begin{array}{c}238-757 \\
(466 \pm 147 ; 31.5 \%)\end{array}$ & $\begin{array}{c}235-552 \\
(368 \pm 99 ; 26.9 \%)\end{array}$ & $\begin{array}{c}283-683 \\
(476 \pm 108 ; 22.7 \%)\end{array}$ \\
\hline Total Phosphorus ${ }^{* *}\left(\mu \mathrm{g} \cdot \mathrm{L}^{-1}\right)$ & $\begin{array}{c}3-66 \\
(14 \pm 18 ; 128.6 \%)\end{array}$ & $\begin{array}{c}0-9 \\
(5 \pm 2 ; 40.0 \%)\end{array}$ & $\begin{array}{c}0-18 \\
(15 \pm 20 ; 133.3 \%)\end{array}$ \\
\hline
\end{tabular}

${ }^{*} \mathrm{n}=23 ;{ }^{* *} \mathrm{n}=12$; Mean, standard deviation and coefficient of variation (\%), in parentheses. 
variation coefficients between $40 \%$ (pelagic zone) and $133.3 \%$ (littoral zone 3 ).

Phytoplankton community biovolume was higher in the littoral zone: $11.4 \pm 7.2 \mathrm{~mm}^{3} \cdot \mathrm{L}^{-1}$ (station 1) and $11.0 \pm 17.5 \mathrm{~mm}^{3} \cdot \mathrm{L}^{-1}$ (station 3 ) (Table 2). In the pelagic zone the mean biovolume never exceeded $6.0 \mathrm{~mm}^{3} . \mathrm{L}^{-1}$ (Figure 3). Significant differences were observed between the sampling points (ANOVA, $\mathrm{F}=19.29, \mathrm{p}=0.00$ ).

There were no significant differences between sampling points 1 and 3 in the littoral zone (Duncan test, $\mathrm{p}=0.08$ ). Total biovolume of the pelagic zone was somewhat lower than that nearshore. Littoral zone 3 showed a biomass peak in the dry season in
October $2005\left(82.0 \mathrm{~mm}^{3} . \mathrm{L}^{-1}\right)$ (Figure 3), due to the presence of large filamentous algae.

Peridinium umbonatum was a descriptor species (above $5 \%$ of the total biovolume of the phytoplankton community per sampling unit) in $88 \%$ of the samples, more than half of the total biovolume in $13 \%$ of them (Figure 3). No significant difference was observed in P. umbonatum biovolume between the sampling stations (ANOVA, $\mathrm{F}=2.81, \mathrm{p}=0.07)$. However, through the Duncan test we could verify that this alga did not show a statistical difference in its biovolume between the pelagic and the littoral zone 1 (Duncan test, $\mathrm{p}=0.14)($ Table 2$)$.
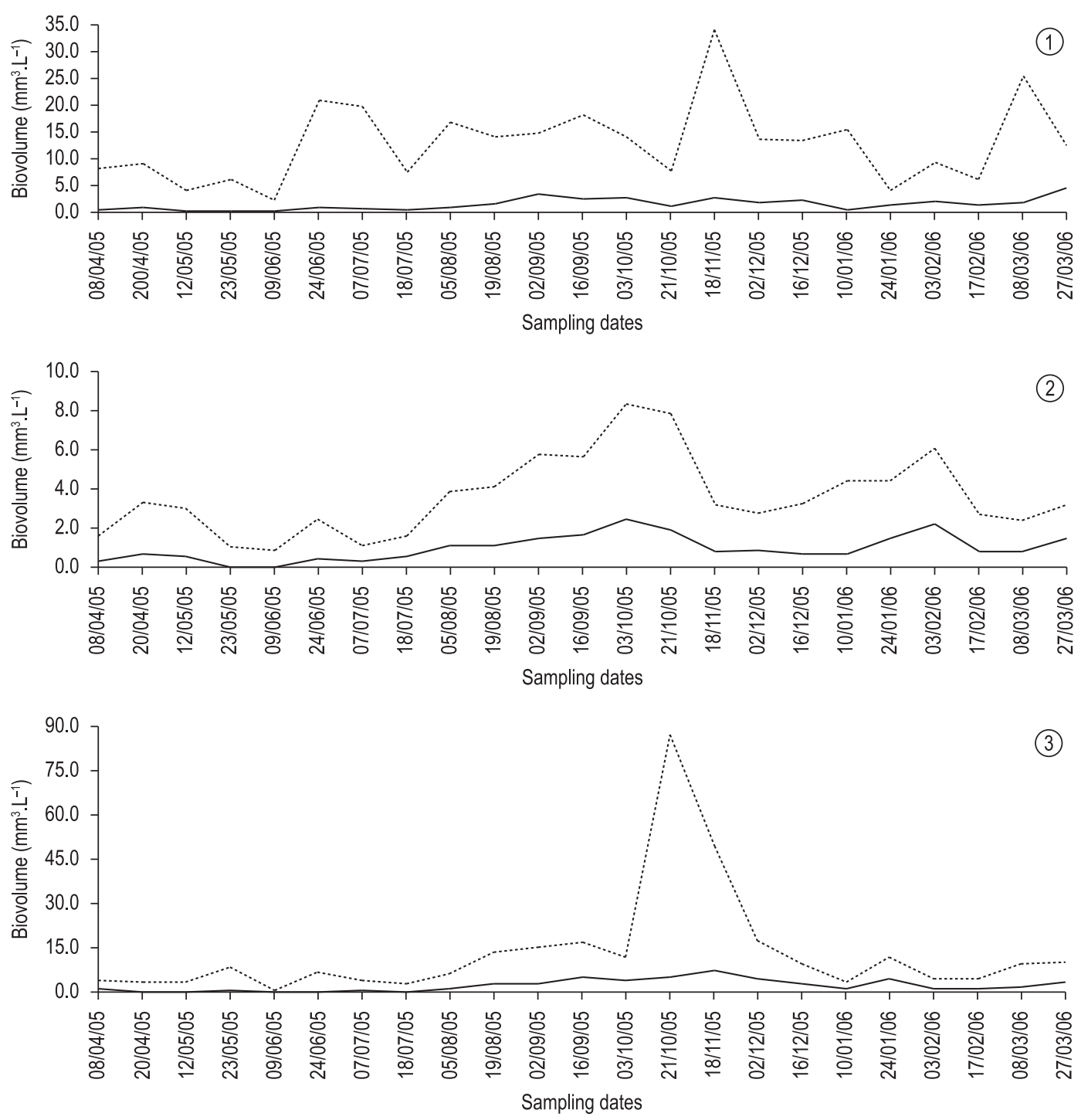

— P. umbonatum ….. Total biovolume

Figure 3. Biovolume (ind. $\mathrm{mL}^{-1}$ ) of the phytoplankton community and relative biovolume (\%) of Peridinium umbonatum at littoral zone (stations 1 and 3) and pelagic zone (station 2) of Lagoon Bonita from April/2005 to March/2006. 
Table 2. Descriptive statistics of biovolume (means $\pm \mathrm{sd}$, minimum - maximum) of Peridinium umbonatum and total phytoplankton $(n=23)$ of Lagoon Bonita between April/2005 and March/2006.

\begin{tabular}{ccc}
\hline Point & \multicolumn{2}{c}{ Biovolume $\left(\mathrm{mm}^{3} . \mathrm{L}^{-1}\right)$} \\
\cline { 2 - 3 } & $P$. umbonatum & Total \\
\hline 1 Littoral zone & $1.5 \pm 1.1$ & $11.4 \pm 7.2$ \\
& $0.2-4.4$ & $2.1-31.4$ \\
2 Pelagic zone & $1.0 \pm 0.7$ & $2.6 \pm 1.5$ \\
& $0-2.4$ & $0.8-6.0$ \\
3 Littoral zone & $2.3 \pm 2.1$ & $11.0 \pm 17.5$ \\
& $0-7.5$ & $0.7-82.0$ \\
\hline
\end{tabular}

\section{Discussion}

Peridinium umbonatum and the phytoplankton showed higher values of biovolume in the littoral zone. This spatial difference may be related to the presence of floating and submerged macrophytes in the littoral zone; whereas in the pelagic zone, submerged aquatic plants are dominant. Together, both types of plants form traps for particles and associated nutrients (Kalff, 2002).

Submerged vegetation can affect the phytoplankton community in both composition and biomass. Mainly in shallow lakes, vegetation plays an important role in the formation of a clear-water environment dominated by macrophytes, rather than turbid waters dominated by phytoplankton (Scheffer, 1998, 2001; Scheffer and Van Nes, 2007). Submerged macrophytes hinder sediment resuspension and collect nutrients from water (Scheffer, 2001).

Aquatic macrophytes of the Lagoon Bonita littoral zone, by reducing the turbulence in that region, can cause sedimentation of the allochthonous material from the grain crops situated near one area of the shore. The plants also function as charge filters, either in suspension or in solution, drained from the surroundings. This would explain the low conductivity and nutrient concentrations in the lake. A similar situation was observed by Marinho (1994) in Jacaré pond, in São Paulo. The structural difference of the phytoplankton community between the Lagoon Bonita sampling points may result mainly from the presence or absence of these aquatic plants.

Dinoflagellates inhabit oligotrophic environments and can be found in all types of lakes (Rosen, 1981). This algae group is also common in well-oxygenated environments, and is tolerant of wide ranges of $\mathrm{pH}$ and luminosity conditions (Pollingher, 1988). The oligotrophic characteristics of Lagoon Bonita may explain the occurrence of the dinoflagellate $P$. umbonatum.

The analyses at Lagoon Bonita indicated very low phosphorus concentrations in the water column. In general, the Peridinium genus is favored under conditions of low nutrients availability, specially phosphorus, once it has developed adaptive strategies such as motility and "luxury consumption" (Serruya and Bermann, 1975; Pollinger 1988). Yet, they are S-strategists (sensu Reynolds) and are inserted in the Reynolds et al. Lo group (2002) (Lo = Habitat template: deep and shallow, oligo to eutrophic, medium to large lakes).

Although, P. umbonatum is rarely dominant, it is widely distributed in lakes and brazilian reservoirs (Cardoso and Torgan, 2007; DelazariBarroso et al., 2007; Ferragut et al., 2005; Fonseca and Bicudo, 2010; Garcia and Vélez, 1995; Nabout and Nogueira, 2007; Silva, 1999). Oda and Bicudo (2006) recorded the occurrence of higher densities of $P$. umbonatum and $P$. gatunense in periods of greatest nutrient deficiency (except for silicates) in a shallow oligotrophic reservoir in the city of São Paulo.

Both, the temporal and spatial scales were relevant in the presence of $P$. umbonatum, and the spatial heterogeneity was the dominant factor along the study period. The plant community structure, mainly submersed macrophytes, has affected the P. umbonatum population dynamics that took place at shallow, nutrient-poor conditions, smallsize lake, which matches with habitat template described to Lo functional classification established by Reynolds et al. (2002).

\section{Acknowledgements}

The authors are grateful to CAPES for granting a scholarship to Patrícia Pereira Gomes; to the Water and Wastewater Treatment Company of Brasília (CAESB) for nutrient analysis; and to the staff of the Estação Ecológica de Águas Emendadas for logistical support during fieldwork.

\section{References}

American Public Health Association - APHA., 1995. Standard methods for the examination of water and wastewater. $19^{\text {th }}$ ed. New York: APHA. 1268 p.

AQUINO-LEITE, ALT., 1990. Desmidiaceae (Chlorophyta) e os fatores físico-químicos da Lagoa Bonita, Distrito Federal, Brasil. Brasília, Universidade de Brasília - UnB. [Master's Thesis].

ARAÚJO, MFF., COSTA, IAS. and CHELLAPPA, NT., 2000. Comunidade fitoplanctônica e variáveis 
ambientais na Lagoa de Extremoz, Natal-RN, Brasil. Acta Limnologica Brasiliensia, vol. 12, p. 127-140.

AYRES, M., AYRES Jr., M., AYRES, DL. and SANTOS, AS., 2003. Bioestat 3.0: aplicaçóes estatísticas nas áreas das ciências biológicas e médicas. Belém: Sociedade Civil Mamirauá; Brasília: CNPq. 290 p.

BICUDO, CEM. and MENEZES, M., 2005. Gêneros de algas de águas continentais do Brasil: chave para identificação e descriçóes. São Carlos: RiMa. 508 p.

CARDOSO, LS. and TORGAN, LC., 2007. Dinoflagelados em diversos habitats e hidroperíodos na zona costeira do sul do Brasil. Acta Botanica Brasilica, vol. 21, no. 2, p. 411-419.

DELAZARI-BARROSO, A., SANT'ANNA, CL. and SENNA, PA., 2007. Phytoplankton from Duas Bocas reservoir, Espírito Santo State, Brazil (except diatoms). Hoehnea, vol. 34, no. 2, p. 211-229.

FERRAGUT, C., LOPES, MRM., BICUDO, DC., BICUDO, CEM. and VERCELLINO, IS., 2005. Ficoflórula perifítica e planctônica (exceto Bacillariophyceae) de um reservatório oligotrófico raso (Lago do IAG, São Paulo). Hoehnea, vol. 32, no. 2, p. 137-184.

FONSECA, BM. and BICUDO, CEM., 2010. How important can the presence/absence of macrophytes be in determining phytoplankton strategies in two tropical shallow reservoirs with different trophic status? Journal of Plankton Research, vol. 32, no. 1, p. 31-46.

FONSECA, BM., 2005. Diversidade fitoplanctônica como discriminador ambiental em dois reservatórios rasos com diferentes estados tróficos no Parque Estadual das Fontes do Ipiranga, São Paulo, SP. São Paulo: Universidade de São Paulo - USP, [PhD Thesis].

FRANCESCHINI, IM., 1992. Algues d'eau douce de Porto Alegre, Brésil (les Diatomophycées exclués). Berlin: J. Cramer. Bibliotheca Phycologica, no. 92.

GARCIA, M. and VÉLEZ, E., 1995. Algas planctônicas da Lagoa Emboaba, Planície Costeira do Rio Grande do Sul: avaliação qualitativa. Boletim do Instituto de Biociências da Universidade Federal do Rio Grande do Sul, vol. 54, p. 75-114.

GOMES, PP., 2007. Variação espacial e temporal da comunidade fitoplanctônica da Lagoa Bonita, DF. Brasília: Universidade de Brasília - UnB. [Master Thesis].

GRIGORSZKY, I., BORICS, G., PADISÁK, J., TÓTMÉRÉSZ, B., VASAS, G., NAGY, S. and BORBÉLY, G., 2003. Factors controlling the occurrence of Dinophyta species in Hungary. Hydrobiologia, vol. 506-509, no. 1, p. 203-207.

HILLEBRAND, H., DÜRSELEN, C., KIRSCHTEL, D., POLLINGHER, U. and ZOHARY, T., 1999. Biovolume calculation for pelagic and benthic microalgae. Journal of Phycology, vol. 35, p. 403-424.
KALFF, J., 2002. Limnology: inland water ecosystems. New Jersey: Prentice Hall. p. 592.

MARINHO, MM. Dinâmica da comunidade fitoplanctônica de um pequeno reservatório raso, densamente colonizado por macrófitas aquáticas submersas (Açude do Jacaré, Mogi Guaçu, SP, Brasil). Sáo Paulo: Universidade de São Paulo - USP, 1994.

MOSCHINI-CARLOS, V., PEREIRA, D., WISNIEWSKI, MJS. and POMPEO, MLM., 2008. The planktonic community in tropical interdunal ponds (Lençóis Maranhenses National Park, Maranhão State, Brazil). Acta Limnologica Brasiliensia, vol. 20, no. 2, p. 99-110.

NABOUT, JC. and NOGUEIRA, IS., 2007. Spatial and temporal dynamics of phytoplankton functional group in a blocked valley (Brazil). Acta Limnologica Brasiliensia, vol. 19, no. 3, p. 305-314.

NIE, NH., HULL, CH., JENKINS, JG., STEINBRENNER, K. and BENDT, DH., 1981. SPSS - Statistical package for the social sciences. $2^{\text {nd }}$ ed. New York: McGraw-Hill. 675 p.

ODA, ACR. and BICUDO, CEM., 2006. Ecology of Peridinium gatunense and Peridinium umbonatum (Dinophyceae) in a shallow, tropical, oligotrophic reservoir (IAG Pond), São Paulo, southeast Brazil. Acta Limnologica Brasiliensia, vol. 18, no. 2, p. 165-180.

POLLINGHER, U., 1988. Freshwater armored dinoflagellates: growth, reproduction, strategies, and population dynamics. In: SANDGREN, CG., ed. Growth and reproductive strategies of freshwater phytoplankton. Cambridge: Cambridge University Press. p. 134-174.

POPOVSKÝ, J. and PFIESTER, LA., 1990. Dinophyceae (Dinoflagellida). In ETTL, H., GERLOFF, J., HEYNING, H. and MOLLENHAUER, D., ed. Das Süsswasserflora von Mitteleuropa. Stuttgart: G. Fischer Verlag. 263 p.

REYNOLDS, CS., HUSZAR, V., KRUK, C., NASELLI-FLORES, L. and MELO, S., 2002. Towards functional classification of the freshwater phytoplankton. Journal of Plankton Research, vol. 24, no 5., p. 417-428.

ROSA, ZM., UNGARETTI, I., KREMER, LM., SILVA, SMA., CALLEGARO, VLM. and WERNER, VR., 1987. Ficoflora de ambientes lênticos - Estudo preliminar da região de Charqueadas, Rio Grande do Sul, Brasil, com vistas à avaliação ambiental. Acta Botanica Brasilica, vol. 1, no. 2, p. 165-188.

ROSEN, G. Phytoplankton indicators and their relations to certain chemical and physical factors. Limnologica, 1981, vol. 13, p. 236-296.

ROTT, E., 1981. Some results from phytoplankton counting intercalibrations. Schweizerische Zeitschrift Fur Hydrologie, vol. 43, no. 1, p. 34-53. 
SCHEFFER, M. and VAN NES, EH., 2007. Shallow lakes theory revisited: various alternative regimes driven by climate, nutrients, depth and lake size. Hydrobiologia, vol. 584, p. 455-466.

SCHEFFER, M., 1998. Ecology of shallow lakes. London: Chapman \& Hall. 357 p.

SCHEFFER, M., 2001. Alternative attractors of shallow lakes. The Scientific World, vol. 1, p. 254-263.

SERRUYA, C. and BERMANN, T., 1975. Phosphorus, nitrogen and growth of algae in Lake Kinneret. Journal of Phycology, vol. 11, p. 155-162.

SILVA, LHS., 1999. Fitoplâncton de um reservatório (Lago Monte Alegre), Ribeirão Preto, São Paulo, Brasil. Revista Brasileira de Biologia, vol. 59, no. 2, p. 281-303.

SOMMER, U., 1988. Some size relationships in phytoflagellate motility. Hydrobiologia, vol. 161, no. 1, p. 125-131.

SØNDEGAARD, M. and MOSS, B., 1998. Impact of submerged macrophytes on phytoplankton in shallow freshwater lakes. In JEPPENSEN, E., SØNDEGAARD, M. and CHRISTOFFERSEN, K., ed. The Structuring role of submerged macrophytes in lakes. NY: Springer Verlag. p. 115-132. Ecological Studies, vol. 131.

SUN, J. and LIU, D., 2003. Geometric models for calculating cell biovolume and surface area for phytoplankton. Journal of Plankton Research, vol. 25, no. 11, p. 1331-1346.

TAYLOR, FJR., 1987. Dinoflagellate morphology. In TAYLOR, FJR., ed. The biology of dinoflagellates. Oxford: Blackwell Scientific Publications, 1987. p. 24-91.

UTERMÖHL, H., 1958. Zur Vervollkommung der quantitativen Phytoplankton-Methodik. Mitteilungen Internationale Vereinigung Limnologie, vol. 9, p. 1-38.

VAN DEN HOEK, C., MANN, DG. and JAHNS, HM., 1995. Algae: an introduction to phycology. Cambridge: Cambridge University Press. 627 p.

WETZEL, RG. and LIKENS, GE., 2001. Limnological analysis. In WETZEL, RG., ed. Limnology - Lake and river ecosystems. USA: Academic Press. 1006 p.

Received: 19 November 2009 Accepted: 01 February 2011 